\title{
Role of bone morphogenetic proteins in adrenal physiology and disease
}

\author{
Inga K Johnsen and Felix Beuschlein \\ Department of Medicine, Endocrine Research, University Hospital Innenstadt, Ludwig Maximilians University, Ziemssenstrasse 1, D-80336 Munich, Germany \\ (Correspondence should be addressed to F Beuschlein; Email: felix.beuschlein @med.uni-muenchen.de)
}

\begin{abstract}
Bone morphogenetic proteins (BMPs) are members of the transforming growth factor- $\beta$ superfamily of ligands that impact on a multitude of biological processes including cell type specification, differentiation and organogenesis. Furthermore, a large body of evidence points towards important BMP-dependent mechanisms in tumorigenesis. In accordance with their diverse actions, BMPs have been demonstrated to serve as auto-, para- and endocrine modulators also in a number of hormonal systems. In this review, we highlight novel aspects of BMP-dependent regulatory networks that pertain to adrenal physiology and disease, which have been uncovered during recent years. These aspects include the role of BMP-dependent mechanism during adrenal development, modulating effects on catecholamine synthesis and steroidogenesis and dysregulation of BMP signalling in adrenal tumorigenesis. Furthermore, we summarize potential therapeutic approaches that are based on reconstitution of BMP signalling in adrenocortical tumour cells.
\end{abstract}

Journal of Molecular Endocrinology (2010) 44, 203-211

\section{Introduction}

Bone morphogenetic proteins (BMPs) are cytokines belonging to the transforming growth factor- $\beta$ (TGF- $\beta$ ) superfamily, which have been originally identified by their capacity to induce endochondral bone formation (Hogan 1996). On an evolutionary scale, BMP signalling is highly conserved over at least 700 million years (Blitz \& Cho 2009). Accordingly, BMP-dependent functions are involved in a multitude of biological processes. Among their many functional properties, BMPs control cell type specification, differentiation and organogenesis (von Bubnoff \& Cho 2001). Furthermore, they have been demonstrated to act as auto- or paracrine modifiers of tumour growth and to have functional impact in a number of cancer entities (Langenfeld et al. 2003, Hsu et al. 2005).

BMPs are synthesized as large precursor proteins and are proteolytically cleaved upon dimerization to yield active proteins. These mature dimers initiate signalling by binding to transmembrane serine/threonine kinase receptors. Notably, BMPs display different binding affinities to individual BMP and activin receptors (ActRs). BMP-6, for example, primarily binds to ActRI (Alk 2), whereas BMP-2 and BMP-5 mainly signal through BMPR1A (Alk 3) and BMPR1B (Alk 6; Liu et al. 1995, Yamashita et al. 1995). Upon ligand binding, type II receptor transphosphorylates type I receptor, which in turn phosphorylates receptorregulated SMAD proteins. These receptor SMADs (i.e. SMAD1, SMAD5 and SMAD8 for BMP signalling) heterodimerize with the common partner SMAD4 and translocate into the nucleus, where they activate or repress BMP target genes (e.g. inhibitor of DNA-binding proteins, ID proteins) depending on the recruitment of further co-factors (von Bubnoff \& Cho 2001, Chen et al. 2004). In contrast, TGF- $\beta$ signalling is primarily transduced by receptor SMADs SMAD2 and SMAD3, which are activated after TGF- $\beta$ binding and receptor complex formation (TGF- $\beta$ R2 with TGF- $\beta R 1$ (Alk 5), Alk 1 or Alk 2).

BMPs are under tight regulation through proteins with antagonistic properties including extracellular noggin (Zimmerman et al. 1996) and follistatin (Iemura et al. 1998, Phillips \& de Kretser 1998) and intracellular inhibitory SMADs among others (Hayashi et al. 1997, Imamura et al. 1997, Nakao et al. 1997). Besides this canonical pathway, BMPs have been reported to modulate also a number of other cascades, including the mitogen-activated protein kinase-extracellular signalregulated kinase (MAPK-ERK) pathway, AKT-phosphatidylinositol 3-kinase (PI3K) pathway, $\beta$-catenin/WNT pathway (Ghosh-Choudhury et al. 2002, He et al. 2004, Nohe et al. 2004) and the stress activated protein kinase-c-JUN N-terminal kinase (SAPK/JNK) pathway 
(Goto et al. 2009). This crosstalk can partially explain the observed complexity, diversity and flexibility of BMP-induced cellular responses (Guo \& Wang 2009).

In accordance with their diverse actions, BMPs have been demonstrated to serve as auto-, para- and endocrine modulators also in a number of hormonal systems. In this review, we will specifically highlight novel aspects of BMP-dependent regulatory networks that pertain to adrenal physiology and disease, which have been uncovered during recent years.

\section{BMPs in adrenal development}

BMPs have been demonstrated to be involved in a variety of key developmental processes such as dorsal-ventral axis specification, epithelial-mesenchymal interactions and apoptosis (Liu \& Niswander 2005). However, as most genetically modified animal models with disrupted BMP signalling are prone to early intrauterine death (Mishina et al. 1995, Huber 2006), in vivo studies detailing BMP-dependent mechanisms required for adrenal gland development are sparse. Indirect evidence for the importance of BMP signalling in adrenal development has been gathered in sheep of the Booroola phenotype. In these animals, which are mainly defined by an increased rate of ovulation and an increased litter size, a spontaneously occurring mutation in BMPR1B had been identified (Mulsant et al. 2001). Interestingly, this mutation which results in a single amino acid substitution of the BMPR1B and reduction of BMP-4-induced signalling in granulosa cells (Fabre et al. 2003) is associated with smaller adrenal size in affected young animals, whereas the weight of heart, liver, lungs and kidneys was found to be unchanged (Souza \& Baird 2004).

In addition to these gross anatomical observations, more refined mechanistic experiments have provided support for BMP-dependent regulation of adrenal development, specifically of adrenomedullary cell specification from the neural crest. The neural crest itself emerges from the dorsal surface of the neural tube and generates a population of multipotent progenitor cells, which have the capacity to give rise to both sympathetic neurons and chromaffin cells located in the adrenal medulla (Huber 2006). Chromaffin cell differentiation is believed to involve the inhibition of terminal neuronal differentiation with downregulation of neurofilament expression and lack of neurite growth (Michelsohn \& Anderson 1992). Tissues surrounding neural crest cells and sympathoadrenal progenitor cells during their migration and at their final locations are considered to be important for the induction of a sympathetic neuronal or chromaffin cell phenotype. In this context, it is widely assumed that BMPs from the wall of the dorsal aorta in concert with cell-specific transcription factors are required for the specification of sympathoadrenal cells (Schneider et al. 1999). This hypothesis is based on an increasing body of evidence gathered in in vitro and in vivo models: BMP-2, BMP-4 and BMP-7 have been demonstrated to increase the number of catecholaminergic and neuronal cells in culture of avian neural crest cells, and overexpression of BMP-4 in chicken embryo is sufficient to induce cells ectopically expressing sympathoadrenal-specific markers (Reissmann et al. 1996). Similarly, introduction of a constitutively active type I $\mathrm{BMP}$ receptor in neural crest cells is sufficient to induce the development of adrenergic cells (Varley et al. 1998). However, BMP-2 and BMP-4 can also induce apoptosis in cultured sympathoadrenal progenitor cells, which are counteracted by addition of fibroblast growth factor and nerve growth factor. It has been proposed that exposure of progenitor cells to pro-apoptotic factors such as BMP-2/BMP-4 make them transiently dependent on other target-derived factors for their survival and development (Song et al. 1998). These apparently contradictory functional properties of BMP-2/BMP-4 could, thus, present an important mechanism at an earlier time point during adrenomedullary development to pre-sort a heterogeneous cell population for a subsequent more effective specification.

In addition to the expression of BMPs in the dorsal aorta and their ability to influence progenitor cell development, members of the BMP family have been discovered to be expressed also in the adrenal cortex. In accordance with the role of BMPs during early development to differentiate progenitor cells towards an adrenergic cell type, BMP-4 originating from adrenocortical cells is able to induce tyrosine hydroxylase $(\mathrm{TH})$ expression in avian TH-negative sympathoadrenal progenitor cells (Huber et al. 2008). Accordingly, noggin, an extracellular acting BMP antagonist, could be demonstrated to prevent the increase of TH-positive cells in adrenal explants without affecting cell proliferation. Overall, these data highlight the importance of timely and spatially fine-tuned distribution of BMPs for the generation of precursor cells, which are required for the proper development of chromaffin cells within the adrenal gland (Fig. 1A). Furthermore, these observations do not apply for all TGF- $\beta$ family members in general. TGF- $\beta$ (isoforms 2 and 3), for example, is synthesized by cells in the wall of the dorsal aorta as well as at later stages in both cortical and migrating chromaffin cells within the developing adrenal gland. However, the in vivo effects of TGF- $\beta$ on chromaffin cells are limited to their inhibiting action on cell proliferation in contrast to that of chromaffin cell phenotype determination as observed for BMPs (Combs et al. 2000, Huber et al. 2002). 

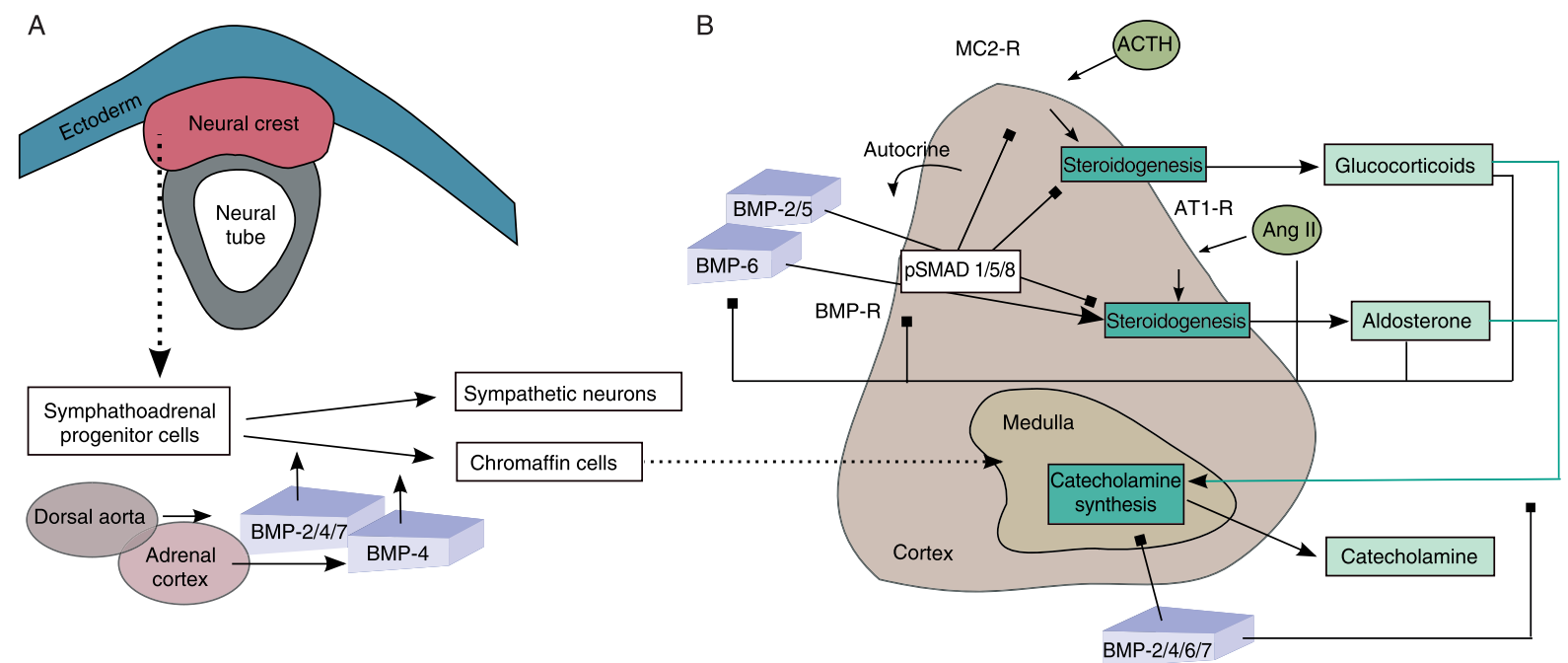

Figure 1 Roles of BMP during adrenal development $(A)$ and endocrine function during adulthood (B). (A) Sympathoadrenal progenitor cells undergo differentiation to adrenomedullary chromaffin cells induced by BMP-2/BMP-4/BMP-7 and secreted by the dorsal aorta and adrenal cortex respectively. (B) Summary of various interrelations of BMPs with adrenocortical steroidogenesis and adrenomedullary catecholamine biosynthesis (for details see text). (MC2-R, melanocortin 2 receptor/ACTH receptor; Ang II, angiotensin II; AT1-R, angiotensin II type 1 receptor; $\longrightarrow$, inhibition; $\longrightarrow$, stimulation).

\section{BMP-dependent mechanisms in adrenal physiology}

\section{Adrenal medulla}

In addition to the developmental context, BMPs secreted locally by the adrenal cortex are good candidates that could also modify the cellular fate of tissue progenitor cells in the adult adrenal medulla. Furthermore, direct functional effects of BMPs on adrenomedullary hormone secretion have been postulated. Owing to the close anatomic connection, functional interdependence between the adrenal cortex and the adrenal medulla had been suspected already in the 1970s (Wurtman et al. 1972). Glucocorticoids secreted by the adrenal cortex were found to be transported mainly through a corticomedullary portal system into the medulla to stimulate the synthesis of catecholamine enzymes and, thus, maintain the phenotype of chromaffin cells (Shepherd \& Holzwarth 2001). Interestingly, BMPs are thought to influence catecholamine production of adrenomedullary cells via an indirect mechanism through interfering with steroid hormone-dependent signalling pathways (Kano et al. 2005, Goto et al. 2009). In rat adrenomedullary PC-12 cells, it has been demonstrated that BMPs can inhibit dopamine expression and reduced DOPA decarboxylase mRNA expression in a dosedependent manner, thereby acting antagonistic to glucocorticoids. Conversely, glucocorticoids could be shown to inhibit BMPRII, Alk 2 as well as Alk 3 expression to maintain catecholamine production, providing a complex but finely regulated system for glucocorticoid-dependent catecholamine synthesis (Kano et al. 2005). Similarly to glucocorticoids, BMPs have the potential to influence aldosterone-dependent dopamine production in PC-12 cells. Aldosterone is capable of functioning through classic genomic mechanisms via stimulation of the mineralocorticoid receptor or to elicit non-genomic signals via the regulation of various second-messenger pathways (Funder 2005). In this context, BMP-4 has been found to enhance aldosterone-induced non-genomic actions on $\mathrm{TH}$ and dopamine synthesis via the $\mathrm{RHO} / \mathrm{SAPK} / \mathrm{JNK}$ pathway, but was not able to stimulate production in the absence of aldosterone (Goto et al. 2009).

Overall, these findings demonstrate a functional interrelationship between adrenocortical cells that produce and secrete both steroid and BMP hormones, and adrenomedullary cells, thereby modulating and fine-tuning adrenal catecholamine output (Fig. 1B).

\section{Adrenal cortex}

In addition to their modulating effects on steroid hormone-dependent mechanisms, BMPs have also been demonstrated to directly impact on steroidogenesis. Aldosterone synthesis and secretion, which is primarily stimulated by angiotensin II (Ang II), potassium, and - within short-term regulation ACTH, have been recognized to be further modulated through an increasing number of growth factors and cytokines (Aguilera 1993, Ehrhart-Bornstein et al. 1998). One of the rate-limiting steps for aldosterone production is the conversion of deoxycorticosterone to aldosterone, which is catalyzed by aldosterone synthase. 
Promoter activation of CYP11B2, which encodes aldosterone synthase, can be induced within minutes upon specific stimulation (Spyroglou et al. 2009). ACTH mainly signals through the cAMP/protein kinase A pathway, whereas Ang II binds to the Ang II type 1 receptor (AT1-R), which is a $\mathrm{G}_{\mathrm{q}}$-protein-coupled receptor and activates inositol trisphosphate $/ \mathrm{Ca}^{2+}$, the diacylglycerine (DAG)/protein kinase $\mathrm{C}(\mathrm{PKC})$ pathway and finally the MAPK-ERK pathway for signalling (Holland et al. 1995, Foster et al. 1997). In vitro experiments in NCIh295R adrenocortical tumour cells have revealed BMP-6-induced and SMAD1/SMAD5/SMAD8-mediated augmentation of aldosterone secretion through a crosstalk with Ang II-dependent pathways (Suzuki et al. 2004, Inagaki et al. 2006). On the contrary, potassium-induced aldosterone production was not found to be influenced by BMP-6. These results were endorsed by experiments following inhibition of endogenous BMP-6 through neutralizing antibodies, which reduced Ang II-induced aldosterone secretion but not potassium-induced aldosterone secretion. These results indicate the possibility that endogenous BMP-6 produced by adrenocortical cells could play an important autocrine role in modulating the steroidogenic actions of Ang II.

Following these findings, it had been suspected that the phenomenon called 'aldosterone breakthrough', which is defined as a state of sustained aldosterone synthesis from the adrenal cortex during long-term treatment with angiotensin converting enzyme (ACE) inhibitors and/or AT1-R blockers (Staessen et al. 1981), could also be mediated by BMP-6. In accordance with this hypothesis, Otani et al. (2008) found that expression of BMP-6 and its receptors was decreased by long-term Ang II exposure but restored by co-treatment with AT1-R blockers. Furthermore, neutralization of Alk 2 and BMP-6 function attenuated the escaping effect from aldosterone suppression by AT1-R blockers. Given the stimulatory effects of BMP-6 on Ang II-induced aldosterone secretion, it is well conceivable that this auto/paracrine mechanism could play an important role in fine-tuning of aldosterone release also in this clinically relevant context.

In contrast to BMP-6, we could recently demonstrate that both BMP-2 and BMP-5 are able to overall suppress forskolin-induced steroidogenesis in NCIh295R cells (Johnsen et al. 2009), similar to what had been reported earlier for TGF- $\beta 1$ (Liakos et al. 2003). Specifically, secretion of aldosterone, cortisol, and dehydroepiandrosterone-sulphate, was reduced by BMP-2 and BMP-5 in a dose-dependent manner. In line with this finding, expression levels of several steroidogenic enzymes, catalyzing the different steps of hormone production, as well as the ACTH receptor (melanocortin 2 receptor, MC2-R), were also inhibited by BMP-2 and BMP-5 treatment in a dose- and time-dependent manner (Johnsen et al. 2009). We further investigated whether BMP-induced decrease in steroidogenesis would be dependent from the transcription factor SF-1, which has been demonstrated to regulate the expression of key determinants of gonadal and adrenal steroidogenesis (Sarkar et al. 2000). Detailed promoter analysis of the $M C 2-R$, utilizing $5^{\prime}$ deletion constructs as well as those harbouring point mutation in SF-1-binding sites, revealed an SF-1-independent mechanism of BMP inhibition on the $M C 2-R$ promoter. Instead, two consensus sites for E-box elements were identified in the last $64 \mathrm{bp}$ fragment of the $M C 2-R$ promoter, which could potentially be targeted by transcription factors of the basic helix-loop-helix (bHLH) family. Interestingly, a subgroup of this family, the ID proteins, function as negative regulators of the bHLH proteins and are targets of BMP-mediated gene transcription. Thus, it is tempting to speculate that the observed BMP-induced inhibition of $M C 2-R$ expression could be mediated by upregulation of ID protein levels. Only recently, in accordance with this concept, studies have reported the involvement of bHLH factors in glucocorticoid secretion by their interaction with the steroid acute regulatory protein (StAR) promoter (Son et al. 2008, Ratajczak et al. 2009) and the regulation of tissuespecific expression of the $M C 2-R$ promoter by E-Box elements (Blondet et al. 2004). Similarly, TGF- $\beta$ has been recognized to inhibit adrenal steroidogenesis through downregulation of StAR (Brand et al. 1998). In addition, TGF- $\beta$-dependent inhibition of CYP11B1 and CYP11B2 promoter activity could be demonstrated (Liakos et al. 2003). Interestingly, while downregulation of StAR was found to be a SMAD dependent but SF-1independent mechanism, TGF- $\beta$-mediated influence on CYP11B1/CYP11B2 promoter displayed a SMADindependent mode of action (Liakos et al. 2003).

In summary, BMPs are important modulators of both catecholamine synthesis and steroidogenesis. They own the potential to govern hormone production as well as enzyme and receptor expression and, moreover, are able to modulate steroidogenic actions by their interactions with involved downstream pathways. The final functional impact, however, depends on the individual member of the BMP family and the particular underlying environmental and cellular conditions, such as presence of participating co-factors and the type and development stage of target cells (Fig. 1B).

\section{Role of BMPs in adrenal tumorigenesis}

\section{Pathophysiological relevance}

A clear indication that BMP signalling pathways can contribute to carcinogenesis comes from genetic studies of familial cancer syndromes. For example, familial juvenile polyposis, an inherited hamartomatous 
polyposis syndrome with a high risk for colon cancer, has been associated with mutations in SMAD4 or BMPR1A (Howe et al. 1998, Zhou et al. 2001). Beyond these familial forms, aberrations in BMP signalling pathways occur in various sporadic human cancers including several endocrine tumour entities such as those deriving from the ovary (Theriault et al. 2007, Le Page et al. 2009), the pituitary (Paez-Pereda et al. 2003, Giacomini et al. 2007) and the thyroid (Franzen \& Heldin 2001). However, the expression levels of individual BMPs not only vary among tumour tissues but each BMP also differs in its functional properties depending on the cell type and tumour stage (Langenfeld \& Langenfeld 2004, Hsu et al. 2005, Langenfeld et al. 2006). In line with this notion, it has been shown that BMP-2 and BMP-3 are down-regulated in prostate (Horvath et al. 2004) and in colorectal cancer (Loh et al. 2008), whereas other members are up-regulated, such as BMP-4 in colorectal tumours or BMP-2 in non-small cell lung carcinomas (Langenfeld et al. 2003, Nosho et al. 2005). Moreover, while several in vitro studies indicate that BMP-2 acts as a growth suppressor in a variety of tumour cell lines (GhoshChoudhury et al. 2000, Mathura et al. 2000, Wong et al. 2003, Otani et al. 2007), there is also evidence that BMP-2 has mitogenic properties in specific lung cancer cell lines (Langenfeld et al. 2003) and can stimulate angiogenesis in developing tumours (Langenfeld \& Langenfeld 2004).

In a recent study detailing expression analysis of members of the TGF- $\beta$ superfamily in human adrenal tissues, we could demonstrate downregulation or loss of expression of BMP-2 and BMP-5 in adrenocortical carcinoma samples in comparison to normal adrenal glands. This lower expression, which was also evident in two adrenocortical cancer cell lines (NCIh295R and SW13), was accompanied by a reduced activity of downstream pSMAD1/pSMAD5/pSMAD8 and ID proteins. BMP-2/BMP-5 treatment of the adrenocortical tumour cell lines resulted in a dose- and timedependent reduction of cellular proliferation and viability, demonstrating the general potential of BMPs to inhibit adrenocortical tumour growth (Johnsen et al. 2009). Treatment of adrenocortical tumour xenografts hosted in nude mice with rhBMP-5 further reinforces BMP-mediated growth decelerating properties. These BMP-induced effects on cell proliferation may be partially explained by their ability to modulate insulinlike growth factor (IGF)-mediated signalling. In fact, it has been shown that BMPs are able to counteract the PI3K/AKT pathway, which mediates IGF-dependent actions on proliferation, apoptosis and cell survival in the adrenal cortex (Doepfner et al. 2007, Giulia et al. 2008). Notably, IGF2 is often overexpressed in adrenocortical tumours and carcinomas and is regarded as one of the most important growth factors for adrenal tumorigenesis (Gicquel et al. 1994, Giordano et al. 2003). For neural cell growth, an IGF/EGF-dependent activation of AKT/ERK kinases has been postulated, which inhibits BMP-induced SMAD signalling through phosphorylation of SMAD proteins within their linker regions, resulting in a diminished nuclear translocation of SMAD heterodimers (Pera et al. 2003). Whether this mechanism also holds true in the context of adrenal tumorigenesis is yet to be elucidated.

\section{Potential therapeutic implications}

The shortcoming in detailed knowledge of underlying molecular pathways involved in adrenal tumorigenesis contributes to the lack of target-specific and patienttailored therapies, which are therefore associated with substantial toxic side effects (Allolio \& Fassnacht 2006, Terzolo et al. 2007). In this context, the finding of abrogated BMP signalling in adrenocortical carcinomas

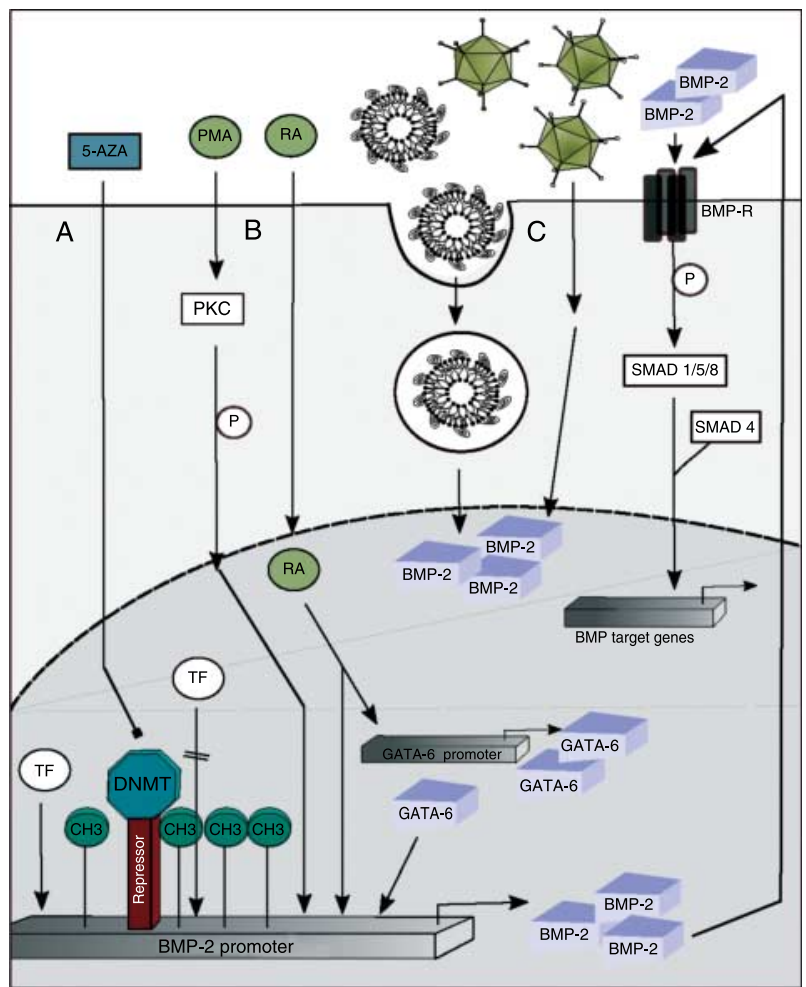

Figure 2 Strategies to enforce BMP expression in adrenocortical tumour cells. (A) Enhancement of endogenous BMP expression through promoter demethylation by 5 -aza-2'-deoxycytidin (5-AZA), thereby inhibiting DNA methylation transferases (DNMTs). (B) Upregulation of BMP expression through PKC pathway activation by phorbol ester PMA. Retinoid acid (RA) treatment for direct BMP promoter activation and upregulation of GATA- 6 transcription with secondary stimulation of BMP expression. (C) Direct gene delivery for BMP overexpression via liposomal or viral vectors. (TF, transcription factors; $\mathrm{CH}$, methylation groups; $\longrightarrow$, inhibition; $\longrightarrow$, stimulation). 
(ACC) could provide a novel target for pharmacological interventions (Fig. 2).

Specifically, restoration of silenced BMP expression could be aimed for to inhibit adrenocortical tumour growth. While hypermethylation of BMP-2 promoter regions has been reported to be the cause of diminished BMP-2 expression in prostate and gastric tumours (Horvath et al. 2004, Wen et al. 2006), this could not be demonstrated in ACC. However, in vitro treatment of NCIh295R cells with the demethylation agent 5-aza-2'-deoxycytidin (5-AZA) was followed by a decrease in BMP-2 promoter methylation, which was further associated with re-expression of endogenous BMPs and activation of downstream IDs (Johnsen et al. 2009). Whether these effects are the direct consequence of BMP-2 promoter demethylation or that of treatmentinduced global epigenetic modifications cannot be answered from these in vitro experiments. However, despite its unspecific mode of action, 5-AZA-dependent treatment protocols for myelodysplastic syndrome and chronic myelomonocytic leukaemia have been associated with a rather restricted profile of documented side effects (Jabbour et al. 2008). Whether demethylation-based therapies can alter the phenotype of adrenocortical cancer in a clinically meaningful manner remains to be determined in future studies in appropriate in vivo models.

Another interesting approach to reactivate BMP signalling in adrenocortical tumour tissues could rely on stimulation of BMP expression through transcription factors such as the GATA-6 or through pharmaceutical agents including 9-cis-retinoid acid (RA) and PKC activators (such as the phorbol ester PMA), which have been described to stimulate BMP expression in extra-adrenal tissues (Sakaue et al. 1996, Sugiura 1999, Helvering et al. 2000). In line with these reports, overexpression of GATA-6 in NCIh295R cells was able to reconstitute BMP-5 expression and induced BMP-2 promoter activity, and similar effects were observable upon treatment with 9-cis-RA and PMA (Johnsen et al. 2009). Retinoid acids are under investigation in clinical trials for the chemical prevention of breast, skin and ovarian cancers (Lippman et al. 1995, Lotan 1995, 1996), whereas bryostatin-1, a specific and potent PKC activator, has revealed anti-tumour effects in lung and prostate tumours (Mohammad et al. 2000, Gonelli et al. 2009). Thus, it is conceivable that similar approaches might have beneficial effects also in the treatment of ACC patients.

Gene delivery that results in reconstitution of BMP expression in target tissues has been described in a growing body of literature in the fields of orthopaedics, orthodontics and tissue engineering (Martinek et al. 2003, Gugala et al. 2007, Chen et al. 2008). Recently, retroviral vectors have been found to be an efficient tool forcing BMP-2 expression in chondrogenic cells and primary articular chondrocytes (Vogt et al. 2008, 2009). Similar results have been obtained with adenoviral vectors yielding high transduction efficiency and long-term gene expression of BMP-2 in autologous bone marrow mesenchymal stem cells (Chen et al. 2008) and primary osteoblast cultures (Egermann et al. 2006). Notably, besides liver targeting, adenoviruses have been demonstrated to have a natural tropism for the adrenal gland, as shown after systemic administration in mice and in non-human primates (Barzon et al. 2004), and adenovirus-based approaches can achieve high levels of transduction efficacy and successful adenoviral gene transfer into adrenocortical cells (Tajima et al. 1999, Alesci et al. 2002, Wolkersdorfer et al. 2002, Matkovic et al. 2009). In general, efficacy and specificity of delivery tools to target tumour sites are improving. These approaches include copolymer-protected vectors (Schillinger et al. 2008), liposomal tools with tumour-targeting affinities (Templeton 2009) and viral vectors with enhanced anti-tumour properties (Alemany 2009). Thus, these findings point towards potential approaches to restore endogenous BMP levels in adrenocortical carcinoma cells for the modulation of their functional properties and malignant potential providing hope for a specific and potent therapy of ACC patients with reduced side effects in the future.

\section{Declaration of interest}

The authors declare that there is no conflict of interest that could be perceived as prejudicing the impartiality of the research reported.

\section{Funding}

This work was supported by grants from the Wilhelm-Sander-Stiftung (2003.145.1 and 2003.145.2) and from the Landesstiftung BadenWürttemberg (P-LS-ASN/5) to F Beuschlein. The authors are further indebted to Dr Christoph Auernhammer and Dr Roland Kappler for fruitful discussions.

\section{References}

Aguilera G 1993 Factors controlling steroid biosynthesis in the zona glomerulosa of the adrenal cortex. Journal of Biochemistry and Molecular Biology 45 147-149.

Alemany R 2009 Designing adenoviral vectors for tumor-specific targeting. Methods in Molecular Biology 542 57-74.

Alesci S, Ramsey WJ, Bornstein SR, Chrousos GP, Hornsby PJ, Benvenga S, Trimarchi F \& Ehrhart-Bornstein M 2002 Adenoviral vectors can impair adrenocortical steroidogenesis: clinical implications for natural infections and gene therapy. PNAS 99 7484-7489.

Allolio B \& Fassnacht M 2006 Clinical review: adrenocortical carcinoma: clinical update. Journal of Clinical Endocrinology and Metabolism 91 2027-2037.

Barzon L, Boscaro M \& Palu G 2004 Endocrine aspects of cancer gene therapy. Endocrine Reviews 25 1-44.

Blitz IL \& Cho KW 2009 Finding partners: how BMPs select their targets. Developmental Dynamics 238 1321-1331. 
Blondet A, Doghman M, Durand P, Begeot M \& Naville D 2004 An E-box-containing region is involved in the tissue-specific expression of the human MC2R gene. Journal of Molecular Endocrinology 32 811-823.

Brand C, Cherradi N, Defaye G, Chinn A, Chambaz EM, Feige JJ \& Bailly S 1998 Transforming growth factor betal decreases cholesterol supply to mitochondria via repression of steroidogenic acute regulatory protein expression. Journal of Biological Chemistry 273 6410-6416.

von Bubnoff A \& Cho KW 2001 Intracellular BMP signaling regulation in vertebrates: pathway or network? Developmental Biology 239 1-14.

Chen D, Zhao M, Harris SE \& Mi Z 2004 Signal transduction and biological functions of bone morphogenetic proteins. Frontiers in Bioscience 9 349-358.

Chen YL, Chen PK, Jeng LB, Huang CS, Yang LC, Chung HY \& Chang SC 2008 Periodontal regeneration using ex vivo autologous stem cells engineered to express the BMP-2 gene: an alternative to alveolaplasty. Gene Therapy 15 1469-1477.

Combs SE, Krieglstein K \& Unsicker K 2000 Reduction of endogenous TGF-beta increases proliferation of developing adrenal chromaffin cells in vivo. Journal of Neuroscience Research 59 379-383.

Doepfner KT, Spertini O \& Arcaro A 2007 Autocrine insulin-like growth factor-I signaling promotes growth and survival of human acute myeloid leukemia cells via the phosphoinositide 3-kinase/Akt pathway. Leukemia 21 1921-1930.

Egermann M, Baltzer AW, Adamaszek S, Evans C, Robbins P, Schneider E \& Lill CA 2006 Direct adenoviral transfer of bone morphogenetic protein-2 cDNA enhances fracture healing in osteoporotic sheep. Human Gene Therapy 17 507-517.

Ehrhart-Bornstein M, Hinson JP, Bornstein SR, Scherbaum WA \& Vinson GP 1998 Intraadrenal interactions in the regulation of adrenocortical steroidogenesis. Endocrine Reviews 19 101-143.

Fabre S, Pierre A, Pisselet C, Mulsant P, Lecerf F, Pohl J, Monget P \& Monniaux D 2003 The Booroola mutation in sheep is associated with an alteration of the bone morphogenetic protein receptor-IB functionality. Journal of Endocrinology 177 435-444.

Foster RH, MacFarlane CH \& Bustamante MO 1997 Recent progress in understanding aldosterone secretion. General Pharmacology 28 $647-651$.

Franzen A \& Heldin NE 2001 BMP-7-induced cell cycle arrest of anaplastic thyroid carcinoma cells via p21(CIP1) and p27(KIP1). Biochemical and Biophysical Research Communications 285 773-781.

Funder JW 2005 The nongenomic actions of aldosterone. Endocrine Reviews 26 313-321.

Ghosh-Choudhury N, Woodruff K, Qi W, Celeste A, Abboud SL \& Ghosh Choudhury G 2000 Bone morphogenetic protein-2 blocks MDA MB 231 human breast cancer cell proliferation by inhibiting cyclin-dependent kinase-mediated retinoblastoma protein phosphorylation. Biochemical and Biophysical Research Communications 272 705-711.

Ghosh-Choudhury N, Abboud SL, Nishimura R, Celeste A, Mahimainathan L \& Choudhury GG 2002 Requirement of BMP-2-induced phosphatidylinositol 3-kinase and Akt serine/ threonine kinase in osteoblast differentiation and Smaddependent BMP-2 gene transcription. Journal of Biological Chemistry 277 33361-33368.

Giacomini D, Acuna M, Gerez J, Nagashima AC, Silberstein S, PaezPereda M, Labeur M, Theodoropoulou M, Renner U, Stalla GK et al. 2007 Pituitary action of cytokines: focus on BMP-4 and gp130 family. Neuroendocrinology 85 94-100.

Gicquel C, Bertagna X, Schneid H, Francillard-Leblond M, Luton JP, Girard F \& Le Bouc Y 1994 Rearrangements at the 11p15 locus and overexpression of insulin-like growth factor-II gene in sporadic adrenocortical tumors. Journal of Clinical Endocrinology and Metabolism 78 1444-1453.

Giordano TJ, Thomas DG, Kuick R, Lizyness M, Misek DE, Smith AL, Sanders D, Aljundi RT, Gauger PG, Thompson NW et al. 2003
Distinct transcriptional profiles of adrenocortical tumors uncovered by DNA microarray analysis. American Journal of Pathology 162 521-531.

Giulia C, Adriana L, Elisabetta P, Poli G, Elisabetta C, Sara M, Tonino E, Andrea G, Mario S, Massimo M et al. 2008 Rosiglitazone inhibits adrenocortical cancer cell proliferation by interfering with the IGF-IR intracellular signaling. PPAR Research 2008904041.

Gonelli A, Mischiati C, Guerrini R, Voltan R, Salvadori S \& Zauli G 2009 Perspectives of protein kinase C (PKC) inhibitors as anticancer agents. Mini Reviews in Medicinal Chemistry 9 498-509.

Goto J, Otsuka F, Yamashita M, Suzuki J, Otani H, Takahashi H, Miyoshi T, Mimura Y, Ogura T \& Makino H 2009 Enhancement of aldosterone-induced catecholamine production by bone morphogenetic protein-4 through activating Rho and SAPK/JNK pathway in adrenomedullar cells. American Journal of Physiology. Endocrinology and Metabolism 296 E904-E916.

Gugala Z, Davis AR, Fouletier-Dilling CM, Gannon FH, Lindsey RW \& Olmsted-Davis EA 2007 Adenovirus BMP2-induced osteogenesis in combination with collagen carriers. Biomaterials 28 4469-4479.

Guo X \& Wang XF 2009 Signaling cross-talk between TGF-beta/BMP and other pathways. Cell Research 19 71-88.

Hayashi H, Abdollah S, Qiu Y, Cai J, Xu YY, Grinnell BW, Richardson MA, Topper JN, Gimbrone MA Jr, Wrana JL et al. 1997 The MADrelated protein Smad7 associates with the TGFbeta receptor and functions as an antagonist of TGFbeta signaling. Cell 89 1165-1173.

He XC, Zhang J, Tong WG, Tawfik O, Ross J, Scoville DH, Tian Q, Zeng X, He X, Wiedemann LM et al. 2004 BMP signaling inhibits intestinal stem cell self-renewal through suppression of Wntbeta-catenin signaling. Nature Genetics 36 1117-1121.

Helvering LM, Sharp RL, Ou X \& Geiser AG 2000 Regulation of the promoters for the human bone morphogenetic protein 2 and 4 genes. Gene 256 123-138.

Hogan BL 1996 Bone morphogenetic proteins: multifunctional regulators of vertebrate development. Genes and Development 10 $1580-1594$.

Holland OB, Carr B \& Brasier AR 1995 Aldosterone synthase gene regulation by angiotensin. Endocrine Research 21 455-462.

Horvath LG, Henshall SM, Kench JG, Turner JJ, Golovsky D, Brenner PC, O'Neill GF, Kooner R, Stricker PD, Grygiel JJ et al. 2004 Loss of BMP2, Smad8, and Smad4 expression in prostate cancer progression. Prostate 59 234-242.

Howe JR, Roth S, Ringold JC, Summers RW, Jarvinen HJ, Sistonen P, Tomlinson IP, Houlston RS, Bevan S, Mitros FA et al. 1998 Mutations in the SMAD4/DPC4 gene in juvenile polyposis. Science $\mathbf{2 8 0}$ 1086-1088.

Hsu MY, Rovinsky S, Penmatcha S, Herlyn M \& Muirhead D 2005 Bone morphogenetic proteins in melanoma: angel or devil? Cancer Metastasis Reviews 24 251-263.

Huber K 2006 The sympathoadrenal cell lineage: specification, diversification, and new perspectives. Developmental Biology 298 335-343.

Huber K, Combs S, Ernsberger U, Kalcheim C \& Unsicker K 2002 Generation of neuroendocrine chromaffin cells from sympathoadrenal progenitors: beyond the glucocorticoid hypothesis. Annals of the New York Academy of Sciences 971 554-559.

Huber K, Franke A, Bruhl B, Krispin S, Ernsberger U, Schober A, von Bohlen und Halbach O, Rohrer H, Kalcheim C \& Unsicker K 2008 Persistent expression of BMP-4 in embryonic chick adrenal cortical cells and its role in chromaffin cell development. Neural Development 328.

Iemura S, Yamamoto TS, Takagi C, Uchiyama H, Natsume T, Shimasaki S, Sugino H \& Ueno N 1998 Direct binding of follistatin to a complex of bone-morphogenetic protein and its receptor inhibits ventral and epidermal cell fates in early Xenopus embryo. PNAS 95 9337-9342.

Imamura T, Takase M, Nishihara A, Oeda E, Hanai J, Kawabata M \& Miyazono K 1997 Smad6 inhibits signalling by the TGF-beta superfamily. Nature 389 622-626. 
Inagaki K, Otsuka F, Suzuki J, Kano Y, Takeda M, Miyoshi T, Otani H, Mimura Y, Ogura T \& Makino H 2006 Involvement of bone morphogenetic protein-6 in differential regulation of aldosterone production by angiotensin II and potassium in human adrenocortical cells. Endocrinology 147 2681-2689.

Jabbour E, Issa JP, Garcia-Manero G \& Kantarjian H 2008 Evolution of decitabine development: accomplishments, ongoing investigations, and future strategies. Cancer 112 2341-2351.

Johnsen IK, Kappler R, Auernhammer CJ \& Beuschlein F 2009 Bone morphogenetic proteins 2 and 5 are down-regulated in adrenocortical carcinoma and modulate adrenal cell proliferation and steroidogenesis. Cancer Research 69 5784-5792.

Kano Y, Otsuka F, Takeda M, Suzuki J, Inagaki K, Miyoshi T, Miyamoto M, Otani H, Ogura T \& Makino H 2005 Regulatory roles of bone morphogenetic proteins and glucocorticoids in catecholamine production by rat pheochromocytoma cells. Endocrinology 146 5332-5340.

Langenfeld EM \& Langenfeld J 2004 Bone morphogenetic protein-2 stimulates angiogenesis in developing tumors. Molecular Cancer Research 2 141-149.

Langenfeld EM, Calvano SE, Abou-Nukta F, Lowry SF, Amenta P \& Langenfeld J 2003 The mature bone morphogenetic protein-2 is aberrantly expressed in non-small cell lung carcinomas and stimulates tumor growth of A549 cells. Carcinogenesis 24 1445-1454.

Langenfeld EM, Kong Y \& Langenfeld J 2006 Bone morphogenetic protein 2 stimulation of tumor growth involves the activation of Smad-1/5. Oncogene 25 685-692.

Le Page C, Puiffe ML, Meunier L, Zietarska M, de Ladurantaye M, Tonin PN, Provencher D \& Mes-Masson AM 2009 BMP-2 signaling in ovarian cancer and its association with poor prognosis. Journal of Ovarian Research 24.

Liakos P, Lenz D, Bernhardt R, Feige JJ \& Defaye G 2003 Transforming growth factor betal inhibits aldosterone and cortisol production in the human adrenocortical cell line NCI-H295R through inhibition of CYP11B1 and CYP11B2 expression. Journal of Endocrinology 176 69-82.

Lippman SM, Heyman RA, Kurie JM, Benner SE \& Hong WK 1995 Retinoids and chemoprevention: clinical and basic studies. Journal of Cellular Biochemistry. Supplement 22 1-10.

Liu A \& Niswander LA 2005 Bone morphogenetic protein signalling and vertebrate nervous system development. Nature Reviews. Neuroscience 6 945-954.

Liu F, Ventura F, Doody J \& Massague J 1995 Human type II receptor for bone morphogenic proteins (BMPs): extension of the twokinase receptor model to the BMPs. Molecular and Cellular Biology 15 3479-3486.

Loh K, Chia JA, Greco S, Cozzi SJ, Buttenshaw RL, Bond CE, Simms LA, Pike T, Young JP, Jass JR et al. 2008 Bone morphogenic protein 3 inactivation is an early and frequent event in colorectal cancer development. Genes, Chromosomes and Cancer 47 449-460.

Lotan R 1995 Retinoids and apoptosis: implications for cancer chemoprevention and therapy. Journal of the National Cancer Institute 87 1655-1657.

Lotan R 1996 Retinoids in cancer chemoprevention. FASEB Journal 10 1031-1039.

Martinek V, Ueblacker P \& Imhoff AB 2003 Current concepts of gene therapy and cartilage repair. Journal of Bone and Joint Surgery. British Volume 85 782-788.

Mathura JR Jr, Jafari N, Chang JT, Hackett SF, Wahlin KJ, Della NG, Okamoto N, Zack DJ \& Campochiaro PA 2000 Bone morphogenetic proteins-2 and -4: negative growth regulators in adult retinal pigmented epithelium. Investigative Ophthalmology and Visual Science 41 592-600.

Matkovic U, Pacenti M, Trevisan M, Palu G \& Barzon L 2009 Investigation on human adrenocortical cell response to adenovirus and adenoviral vector infection. Journal of Cellular Physiology 220 $45-57$.
Michelsohn AM \& Anderson DJ 1992 Changes in competence determine the timing of two sequential glucocorticoid effects on sympathoadrenal progenitors. Neuron 8 589-604.

Mishina Y, Suzuki A, Ueno N \& Behringer RR 1995 Bmpr encodes a type I bone morphogenetic protein receptor that is essential for gastrulation during mouse embryogenesis. Genes and Development 9 3027-3037.

Mohammad RM, Wall NR, Dutcher JA \& Al-Katib AM 2000 The addition of bryostatin 1 to cyclophosphamide, doxorubicin, vincristine, and prednisone (CHOP) chemotherapy improves response in a CHOP-resistant human diffuse large cell lymphoma xenograft model. Clinical Cancer Research 6 4950-4956.

Mulsant P, Lecerf F, Fabre S, Schibler L, Monget P, Lanneluc I, Pisselet C, Riquet J, Monniaux D, Callebaut I et al. 2001 Mutation in bone morphogenetic protein receptor-IB is associated with increased ovulation rate in Booroola Merino ewes. PNAS 98 5104-5109.

Nakao A, Afrakhte M, Moren A, Nakayama T, Christian JL, Heuchel R, Itoh S, Kawabata M, Heldin NE, Heldin CH et al. 1997 Identification of Smad7, a TGFbeta-inducible antagonist of TGF-beta signalling. Nature 389 631-635.

Nohe A, Keating E, Knaus P \& Petersen NO 2004 Signal transduction of bone morphogenetic protein receptors. Cellular Signalling 16 291-299.

Nosho K, Yamamoto H, Adachi Y, Endo T, Hinoda Y \& Imai K 2005 Gene expression profiling of colorectal adenomas and early invasive carcinomas by cDNA array analysis. British Journal of Cancer 92 1193-1200.

Otani H, Otsuka F, Inagaki K, Takeda M, Miyoshi T, Suzuki J, Mukai T, Ogura T \& Makino H 2007 Antagonistic effects of bone morphogenetic protein- 4 and -7 on renal mesangial cell proliferation induced by aldosterone through MAPK activation. American Journal of Physiology. Renal Physiology 292 F1513-F1525.

Otani H, Otsuka F, Inagaki K, Suzuki J, Miyoshi T, Kano Y, Goto J, Ogura T \& Makino H 2008 Aldosterone breakthrough caused by chronic blockage of angiotensin II type 1 receptors in human adrenocortical cells: possible involvement of bone morphogenetic protein-6 actions. Endocrinology 149 2816-2825.

Paez-Pereda M, Giacomini D, Refojo D, Nagashima AC, Hopfner U, Grubler Y, Chervin A, Goldberg V, Goya R, Hentges ST et al. 2003 Involvement of bone morphogenetic protein 4 (BMP-4) in pituitary prolactinoma pathogenesis through a Smad/estrogen receptor crosstalk. PNAS 100 1034-1039.

Pera EM, Ikeda A, Eivers E \& De Robertis EM 2003 Integration of IGF, FGF, and anti-BMP signals via Smadl phosphorylation in neural induction. Genes and Development 17 3023-3028.

Phillips DJ \& de Kretser DM 1998 Follistatin: a multifunctional regulatory protein. Frontiers in Neuroendocrinology 19 287-322.

Ratajczak CK, Boehle KL \& Muglia LJ 2009 Impaired steroidogenesis and implantation failure in Bmall -/ - mice. Endocrinology 150 1879-1885.

Reissmann E, Ernsberger U, Francis-West PH, Rueger D, Brickell PM \& Rohrer H 1996 Involvement of bone morphogenetic protein-4 and bone morphogenetic protein-7 in the differentiation of the adrenergic phenotype in developing sympathetic neurons. Development 122 2079-2088.

Sakaue M, Kitazawa S, Nishida K, Kitazawa R \& Maeda S 1996 Molecular cloning and characterization of human bone morphogenic protein (BMP)-5 gene promoter. Biochemical and Biophysical Research Communications 221 768-772.

Sarkar D, Kambe F, Hayashi Y, Ohmori S, Funahashi H \& Seo H 2000 Involvement of AP-1 and steroidogenic factor (SF)-1 in the cAMPdependent induction of human adrenocorticotropic hormone receptor (ACTHR) promoter. Endocrine Journal 47 63-75.

Schillinger U, Wexel G, Hacker C, Kullmer M, Koch C, Gerg M, Vogt S, Ueblacker P, Tischer T, Hensler D et al. 2008 A fibrin glue composition as carrier for nucleic acid vectors. Pharmaceutical Research 25 2946-2962. 
Schneider C, Wicht H, Enderich J, Wegner M \& Rohrer H 1999 Bone morphogenetic proteins are required in vivo for the generation of sympathetic neurons. Neuron 24 861-870.

Shepherd SP \& Holzwarth MA 2001 Chromaffin-adrenocortical cell interactions: effects of chromaffin cell activation in adrenal cell cocultures. American Journal of Physiology. Cell Physiology $\mathbf{2 8 0}$ C61-C71.

Son GH, Chung S, Choe HK, Kim HD, Baik SM, Lee H, Lee HW, Choi S, Sun W, Kim H et al. 2008 Adrenal peripheral clock controls the autonomous circadian rhythm of glucocorticoid by causing rhythmic steroid production. PNAS 105 20970-20975.

Song Q, Mehler MF \& Kessler JA 1998 Bone morphogenetic proteins induce apoptosis and growth factor dependence of cultured sympathoadrenal progenitor cells. Developmental Biology 196 $119-127$.

Souza CJ \& Baird DT 2004 The Booroola (FecB) mutation is associated with smaller adrenal glands in young adult ewes. Reproductive Biomedicine Online 8 414-418.

Spyroglou A, Manolopoulou J, Wagner S, Bidlingmaier M, Reincke M \& Beuschlein F 2009 Short term regulation of aldosterone secretion after stimulation and suppression experiments in mice. Journal of Molecular Endocrinology 42 407-413.

Staessen J, Lijnen P, Fagard R, Verschueren LJ \& Amery A 1981 Rise in plasma concentration of aldosterone during long-term angiotensin II suppression. Journal of Endocrinology 91 457-465.

Sugiura T 1999 Cloning and functional characterization of the $5^{\prime}$-flanking region of the human bone morphogenetic protein-2 gene. Biochemical Journal 338 433-440.

Suzuki J, Otsuka F, Inagaki K, Takeda M, Ogura T \& Makino H 2004 Novel action of activin and bone morphogenetic protein in regulating aldosterone production by human adrenocortical cells. Endocrinology 145 639-649.

Tajima T, Okada T, Ma XM, Ramsey W, Bornstein S \& Aguilera G 1999 Restoration of adrenal steroidogenesis by adenovirus-mediated transfer of human cytochrome P450 21-hydroxylase into the adrenal gland of 21-hydroxylase-deficient mice. Gene Therapy 6 1898-1903.

Templeton NS 2009 Nonviral delivery for genomic therapy of cancer. World Journal of Surgery 33 685-697.

Terzolo M, Angeli A, Fassnacht M, Daffara F, Tauchmanova L, Conton PA, Rossetto R, Buci L, Sperone P, Grossrubatscher E et al. 2007 Adjuvant mitotane treatment for adrenocortical carcinoma. New England Journal of Medicine 356 2372-2380.

Theriault BL, Shepherd TG, Mujoomdar ML \& Nachtigal MW 2007 BMP4 induces EMT and Rho GTPase activation in human ovarian cancer cells. Carcinogenesis 28 1153-1162.
Varley JE, McPherson CE, Zou H, Niswander L \& Maxwell GD 1998 Expression of a constitutively active type I BMP receptor using a retroviral vector promotes the development of adrenergic cells in neural crest cultures. Developmental Biology 196 107-118.

Vogt S, Ueblacker P, Geis C, Wagner B, Wexel G, Tischer T, Kruger A, Plank C, Anton M, Martinek V et al. 2008 Efficient and stable gene transfer of growth factors into chondrogenic cells and primary articular chondrocytes using a VSV.G pseudotyped retroviral vector. Biomaterials 29 1242-1249.

Vogt S, Wexel G, Tischer T, Schillinger U, Ueblacker P, Wagner B, Hensler D, Wilisch J, Geis C, Wubbenhorst D et al. 2009 The influence of the stable expression of BMP2 in fibrin clots on the remodelling and repair of osteochondral defects. Biomaterials $\mathbf{3 0}$ 2385-2392.

Wen XZ, Akiyama Y, Baylin SB \& Yuasa Y 2006 Frequent epigenetic silencing of the bone morphogenetic protein 2 gene through methylation in gastric carcinomas. Oncogene 25 2666-2673.

Wolkersdorfer GW, Bornstein SR, Higginbotham JN, Hiroi N, Vaquero JJ, Green MV, Blaese RM, Aguilera G, Chrousos GP \& Ramsey WJ 2002 A novel approach using transcomplementing adenoviral vectors for gene therapy of adrenocortical cancer. Hormone and Metabolic Research 34 279-287.

Wong GA, Tang V, El-Sabeawy F \& Weiss RH 2003 BMP-2 inhibits proliferation of human aortic smooth muscle cells via p21Cip1/Wafl. American Journal of Physiology. Endocrinology and Metabolism 284 E972-E979.

Wurtman RJ, Pohorecky LA \& Baliga BS 1972 Adrenocortical control of the biosynthesis of epinephrine and proteins in the adrenal medulla. Pharmacological Reviews 24 411-426.

Yamashita H, ten Dijke P, Huylebroeck D, Sampath TK, Andries M, Smith JC, Heldin CH \& Miyazono K 1995 Osteogenic protein-1 binds to activin type II receptors and induces certain activin-like effects. Journal of Cell Biology 130 217-226.

Zhou XP, Woodford-Richens K, Lehtonen R, Kurose K, Aldred M, Hampel H, Launonen V, Virta S, Pilarski R, Salovaara R et al. 2001 Germline mutations in BMPR1A/ALK3 cause a subset of cases of juvenile polyposis syndrome and of Cowden and BannayanRiley-Ruvalcaba syndromes. American Journal of Human Genetics 69 704-711.

Zimmerman LB, De Jesus-Escobar JM \& Harland RM 1996 The Spemann organizer signal noggin binds and inactivates bone morphogenetic protein 4. Cell 86 599-606.

Received in final form 29 January 2010

Accepted 3 February 2010

Made available online as an Accepted Preprint 4 February 2010 